NBER WORKING PAPER SERIES

\title{
MEASURING THE LOCATION OF PRODUCTION IN A WORLD OF INTANGIBLE PRODUCTIVE ASSETS, FDI, AND INTRAFIRM TRADE
}

\author{
Robert E. Lipsey \\ Working Paper 14121 \\ http://www.nber.org/papers/w14121 \\ NATIONAL BUREAU OF ECONOMIC RESEARCH \\ 1050 Massachusetts Avenue \\ Cambridge, MA 02138 \\ June 2008
}

This paper was prepared as a lecture at The 2008 World Congress on National Accounts and Economic Performance Measures for Nations, in Arlington, Virginia. I am indebted to Jing Sun for excellent research assistance on the project. The views expressed herein are those of the author(s) and do not necessarily reflect the views of the National Bureau of Economic Research.

NBER working papers are circulated for discussion and comment purposes. They have not been peerreviewed or been subject to the review by the NBER Board of Directors that accompanies official NBER publications.

(C) 2008 by Robert E. Lipsey. All rights reserved. Short sections of text, not to exceed two paragraphs, may be quoted without explicit permission provided that full credit, including (C) notice, is given to the source. 
Measuring the Location of Production in a World of Intangible Productive Assets, FDI, and Intrafirm Trade

Robert E. Lipsey

NBER Working Paper No. 14121

June 2008

JEL No. D2,F23,H25

\begin{abstract}
As production comes to depend more on intangible productive assets, the location of production by multinational firms becomes increasingly ambiguous. The reason is that, within the firm, these assets have no clear geographical location, but only a nominal location determined by the firm's tax or legal strategies.

The effects of these location ambiguities, and the resulting distortions for tax reasons of the location of production, are described and it is estimated that for U.S. firms' affiliates in a few tax havens alone, the exaggeration of value added in those locations amounted, in 2005, to about 4 percent of worldwide affiliate sales, and the exaggeration of sales to about 10 percent of worldwide affiliate sales.

Some possibilities for estimating the location of production that could supersede the present dependence on accounting measures distorted by tax-saving policies are described.
\end{abstract}

\author{
Robert E. Lipsey \\ NBER \\ 365 Fifth Avenue, Suite 5318 \\ New York, NY 10016-4309 \\ and NBER \\ rlipsey@gc.cuny.edu
}


Measuring the Location of Production in a World of Intangible

Productive Assets, FDI, and Intrafirm Trade

Robert E. Lipsey

\section{Introduction}

In 1971, the U.S. Department of Commerce published the $50^{\text {th }}$ Anniversary issue of the Survey of Current Business, entitled "The Economic Accounts of the United States: Retrospect and Prospect.” There was much praise for the work of the Office of Business Economics, the producer of the Survey and the National Accounts. However, on one issue, the measurement of capital consumption, several contributors thought that the official data did not measure what they were supposed to, and that changes were overdue. Edward Denison summarized his objections by saying that "The measure of total capital consumption allowances is consistent neither among components nor over time. The only possible use for the nonfarm components is for tax analysis; they have no relevance to the measurement of output or income.” And, “...for nonfarm business, it consists of historical cost values and reflects whatever service lives and depreciation patterns are allowed at a particular time by tax laws and regulations and by accountants” (p. 40). In 1975, the BEA announced that the upcoming benchmark revision of the national accounts would involve abandoning the dependence on tax return depreciation because it “...is not the proper measure for inclusion in national income and product accounts...” (p. 14).

I suggest in this paper that the same state has now been reached for measures of the location of production, especially production by multinational firms, and the corresponding 
measures of international trade, especially in industries in which intangible and financial capital are major inputs into production. The same problems of ascertaining the location of production exist in domestic measure of regional or state gross product, because much of trade across regions or states is intrafirm trade, the share of production from intangible or financial assets differs among locations, and there are incentives to distort values for tax minimization purposes. The problem extends beyond intrafirm trade, but it is more acute in intrafirm trade because many product valuations escape market tests. In this paper I concentrate attention on distortions in international transactions because there is more information available for them.

As production comes to depend more and more on intangible assets, such as patents, copyrights, technological and scientific knowledge, techniques of management or of production and distribution, product and company logos, and company names, the location of production by multinational firms becomes more and more ambiguous. The reason is that in a multinational firm, these assets have no clear geographical location, but only a nominal location determined by the parent company's tax or legal strategies. The geographical assignment by the firm then determines where production based on these assets is reported to take place, the distribution of production across countries, which sales are exports or imports, and the direction of trade.

If these assignments of intangible assets were made randomly, the only consequence for the measurement of production and trade would be some loss of accuracy of individual observations. There is strong evidence, however, that these assignments are not random, but are made in order to minimize taxes, and that they operate to reduce the measured output of countries with high tax rates on business income and exaggerate the output of low-tax countries. They also tend to exaggerate the imports of high-tax countries and understate their exports. The problem in trade data is probably worse for trade in services than for trade in goods. The 
measurement of trade in goods is anchored more in observable physical crossings of borders, where values must be declared, but it exists also in trade in goods, especially those goods for which much of the value is contributed by intangible assets. The area of ambiguity is also increased by the growth in intrafirm trade, especially trade in parts and components, for which arm’s length transactions, and the corresponding prices, may not exist.

One purpose of the paper is to summarize the evidence for systematic distortions of the values of production and trade and to relate them to their causes. A second purpose is to make some estimates of the extent of the distortions. A third purpose is to suggest possible ways of estimating economic valuations of these quantities by reducing the dependence of these estimates on corporate bookkeeping.

\section{The Sources of Measurement Problems}

There are two main sources of problems in measuring the location of production and the direction of trade. One is the increasing share of intangible and financial inputs into production and the second is the increasing importance of transactions that take place across national borders within multinational firms. For regional accounts, the latter problem arises from transactions within firms across regions. Each of them by itself would give rise to measurement problems, but the combination of the two magnifies the effects of each one.

The most fundamental source of the problems is the fact that more and more production and trade are based on inputs from intangible assets, and to a lesser extent, financial assets, the location of which is difficult or impossible to define. The OECD (2006, p. 34), describes this development, with respect to intangible assets, as “One of the most important commercial developments in recent decades," and the report points particularly to the fact that "it is common for intangible property to be used simultaneously by more than one part of an enterprise.” Thus, 
many intangible assets have no clear geographical location. Their only definite location is a legal one, their ownership. The firm that owns such assets, if it is a multinational firm, can move them from one member of the multinational group to another, changing the nominal geographical location without changing the geographical location of the use of the asset or changing the control of the asset. The effect of such a transaction is to shift the apparent location of the production based on that asset. In the process, the firm may change what had been recorded as production by a location into imports into that location. The OECD urged "....principled rules so as to rule out the possibility of the enterprise's simply nominating one part of the enterprise as the owner (by booking the intangible assets there) irrespective of whether, for example, that part had the experience and/or capacity to assume and manage the risks associated with the intangible property” (p. 35).

What intangible assets are involved? Software is one asset that has been the subject of some literature on international shifting for tax purposes, but there are many others. One news article referred to “...patents on drugs, ownership of corporate logos, techniques for manufacturing processes and other intellectual assets...” A tax lawyer was quoted as calling such moves routine, “...international tax planning 101...”, adding that “...most of the assets that are going to be reallocated as part of a global repositioning are intellectual property...that is where most of the profit is.” (“Key Company Assets Moving Offshore,” New York Times, Nov. 22, 2002).

Many of the same problems arise with the location of production based on the financial assets of a multinational firm, although the valuations of the assets are more easily defined. A transfer of assets from a parent to a wholly-owned or majority-owned affiliate, or a transfer among affiliates, can be valued more reliably than a transfer of intangible assets, but it may 
involve no change in the degree of the parent's control of the asset. Production appears to have shifted its location from one location to another, but all the other inputs into production have remained in the former locations. This issue has increased in importance in the case of the United States as the share of U.S. outward FDI in holding companies has risen.

These measurement problems are not new, but they seem to be growing in importance as more firms and their financial advisors become aware of the potential for reducing taxes by using transactions with foreign affiliates. One possible indication of a growing use of this type of "tax planning” is the rising affiliate share of the net income of U.S. multinationals. The share of nonbank affiliates in the net income of nonbank U.S. multinationals, which had been around a quarter in the early 1980s, reached more than a third in the 1990s and close to half in 2003-2005 (BEA web site, April 9, 2008). That doubling of the affiliate share of net income was much larger than the increase in the affiliates' share of employment or expenditures on fixed assets of these multinationals.

\section{The Distortion of Production and Trade Measures}

The main interest in the mismeasurement or distortion of the location of production has been on the part of tax authorities worried about the loss of tax revenue through such practices as the shifting of profits to low-tax locations. Much of the evidence on the manipulation of corporate data stems from the effort to curb tax avoidance. The main purpose of the OECD report cited above was the creation of a basis for the taxation of multinationals that countries could agree on. However, the issues raised are important for the measurement of trade and output in the national accounts.

One sign of distorted measures of output and its location is the reporting of output and profits in locations where there is little or no input of labor or tangible capital. Another is the 
reporting of ratios of output and profits to tangible inputs that differ to an extreme extent from worldwide norms. The inputs for which location is most reliably measured and least likely to be manipulated are of labor ("people functions" in OECD terminology) and of physical capital in the form of plant and equipment.

Since much of the distortion comes about in connection with trade and other transactions and allocations of income within multinational firms, and the United States collects and publishes the most detailed data on transactions within multinational firms, we can use those data to try to measure the distortions. These intrafirm transactions are a likely place to search for distortions because in many cases it is impossible to find comparable arm's length transactions by which the tax authorities can judge correct values. Much of the intrafirm trade in goods involves unfinished goods at various stages of production, not easily compared across firms. The goods may differ not only in the degree of finishing, but also in the degree to which they incorporate the firm's intangible assets and skills or the peculiarities of the firm's production processes.

One source of information on the distortion of output locations by U.S. multinationals is their reports on operations in tax havens, especially small tax havens with little local consumption, labor force, or physical capital. They may not be the main locations for distortions of output measures, but they have so little real productive activity that the distorted activity measures stand out.

Hines (2005) reported that "Much of reported tax haven income consists of financial flows from other foreign affiliates that parents own indirectly through their tax haven affiliates. Clearly, American firms locate considerable financial assets in foreign tax havens and their reported profitability in tax havens greatly exceeds any measure of their physical presence there” 
(p. 78). Hines goes on to suggest that firms in other countries that largely exempt their firms' foreign income from taxation, such as Germany and the Netherlands, have even stronger incentives to locate investment and income production in tax havens (p. 79).

Other developments in the tax planning strategies of U.S. multinational firms, described by Mutti and Grubert (2006), focus on intangible assets, adding to the possibilities for the parent company to “...increase its earnings abroad from exploiting intangible assets that it develops in the United States...” and “...accomplish the relocation or migration of intangible assets abroad” (p. 2). This is a "relocation" that is obviously a fiction, since the geographical location of a company's intangible assets is indefinable. They can be used in many locations simultaneously.

Some hints about one way in which U.S. multinationals locate their measured production and profits in tax havens is given by Table 1. It shows the ratios of U.S. affiliates' total assets to their employment, employee compensation, and plant and equipment in the world as a whole outside the United States and in several low tax countries. Affiliates in the area called "Other Western Hemisphere,” essentially islands in the Caribbean, own enormous assets relative to their labor input, measured by employment or employee compensation, and their physical capital input, measured by their stock of property, plant, and equipment. For example, while the average ratio of assets to employment around the world in 2005 was about \$1 million per employee, the ratios in the three European countries shown separately were all over \$4 million per employee and those for affiliates in “Other Western Hemisphere” were \$16 million per employee. Within this group, affiliates in Bermuda had assets of almost $\$ 150$ million per employee and those in U.K. Islands in the Caribbean, \$29 million per employee. While worldwide, U.S. affiliates owned assets 27 times their payrolls, those in "Other Western Hemisphere” had assets almost 600 times their payrolls. These ratios could differ across 
Table 1: Ratios of Total Assets to Employment \& Compensation of Employees: US MOFAs, 2005

Ratios of Total Assets (\$ Millions) to

Net Property,

Plant and

Equipment

(\$ Millions)

Compensation
of Employees
(\$ Millions)

Employment

(Thousands)

All countries
Canada
Europe
Ireland
Netherlands
Switzerland
Latin America and Other Western
Hemisphere

Central \& South America

12

27

1,035

5

16

633

17

29

38

49

28

1,513

82

4,283

73

4,469

56

4,675

Other Western Hemisphere

Barbados

Bermuda

UK Islands, Caribbean ${ }^{1}$

Western Hemisphere, n.e.c. ${ }^{2}$

12

45

709

4

13

208

57

593

16,167

81

739

22,168

100

123

1,863

145,830

16

686

29,395

203

6,022

Middle East

5

15

697

Asia Pacific

9

22

643

Hong Kong

31

42

1,531

Singapore

14

37

1,292

1. British Antilles, British Virgin Islands, Cayman Islands, Montserrat.

2. Anguilla, Antigua and Barbuda, Aruba, Bahamas, Cuba, Dominica, French Islands (Caribbean), Grenada, Haiti, Jamaica, Netherlands Antilles, St. Kitts and Nevis, St. Lucia, St. Vincent and the Grenadines, Trinidad and Tobago, United Kingdom Islands (Atlantic).

Source: US Department of Commerce, Bureau of Economic Analysis web site, downloaded in Nov., 2007. 
countries because the industry composition of U.S. affiliates is different. However, industry composition does not explain all of these differences. Ratios for Depository Institutions and for Finance (except depository institutions) and Insurance showed similar wide differences between the tax havens and other countries.

The wide differences among affiliates in different regions with respect to ratios of assets to labor input do not represent differences in physical capital intensity. The areas with high ratios of total assets to labor input were also areas with high ratios of total assets to Property, Plant, and Equipment. The high capital intensity of these affiliates reflected holdings of financial or intangible assets, rather than plant and equipment.

Table 2 displays the “profit-type return” relative to labor compensation for nonbank, majority-owned affiliates in 2005. Profit-type return is defined by the BEA as measuring “...profits before income taxes...” excluding “...nonoperating items (such as special charges and capital gains and losses) and income from equity investments” (U.S. Bureau of Economic Analysis, 2004, p. M-19). That definition leads to an understatement of the degree of distortion by excluding income from equity investments, one of the mechanisms for transferring income.

These ratios are clearly related to the asset ratios of Table 1 . While the worldwide ratios of “profit-type return” to payrolls was 84 percent, the ratio in Switzerland was 160 percent and in Ireland, over 660 percent. Those profitability numbers, large as they are, pale beside those of “Other Western Hemisphere,” averaging over 1000 percent, including over 3000 percent in Barbados and Bermuda. These extremely high ratios of profits to labor income, despite the omission of income from equity investments, were achieved by attributing large amounts of financial or intangible capital to affiliates in those countries that employed very few workers and had little payroll expense. 
Table 2: Ratio of Profit-type Return to Compensation of Employees by Majority-owned Nonbank Affiliates of US Nonbank Parents, (2005)

Ratio of Profit-type Return to Compensation of Employees
All countries
0.840

Canada

0.848

Europe

0.579

Ireland

6.639

Netherlands

0.878

Switzerland

1.614

\section{Latin America and Other Western}

Hemisphere

\subsection{5}

Central \& South America

0.978

Other Western Hemisphere

11.709

Barbados

34.967

Bermuda

36.062

United Kingdom Islands, Caribbean ${ }^{1}$

8.833

Western Hemisphere, n.e.c. ${ }^{2}$

Middle East

1.837

Other Middle East ${ }^{3}$

9.403
Asia Pacific
1.178
Hong Kong
0.953
Singapore
2.978

1. British Antilles, British Virgin Islands, Cayman Islands, Montserrat.

2. Anguilla, Antigua and Barbuda, Aruba, Bahamas, Cuba, Dominica, French Islands (Caribbean), Grenada, Haiti, Jamaica, Netherlands Antilles, St. Kitts and Nevis, St. Lucia, St. Vincent and the Grenadines, Trinidad and Tobago, United Kingdom Islands (Atlantic).

3. Bahrain, Iran, Jordan, Kuwait, Lebanon, Oman, Qatar, Syria and Yemen.

Source:

US Department of Commerce, Bureau of Economic Analysis web site, downloaded in Nov., 2007. 


\section{The Direction of Trade}

The conventions that determine the apparent location of production also determine the reported direction of trade. Meade (1951, p. 34) defined exports as an element of “...demands for goods and services which directly or indirectly cause a demand for factors of production (i.e. for the productive services of land, capital, enterprise and work)...” whose incomes are recorded in the national income. Imports, correspondingly, lead to a demand for “ ...the productive resources of other countries.” That definition invites the question of how to treat output from an intangible asset developed in Country A by Firm X, but allocated to a wholly-owned subsidiary of Firm X in Country B. If the output is then exported, should it be considered an export of Country A or of Country B? A similar question arises if a service is sold by a wholly-owned affiliate of Firm X incorporated in Country B to a buyer in Country C, but the service is performed entirely by employees of parent Firm X in Country A. Should it be treated as an export of Country A or of Country B?

In the case of one service imported into the United States, insurance services, data on U.S. imports from all sources, both U.S. affiliates and others, reveal the ambiguities in the reported location of the production of these services and the meaning of the reported trade (Table 3). U.S. imports of insurance services increased substantially after 2001, and the tiny islands of the Caribbean were responsible for almost half the imports, and sometimes more.

An obvious question about the $\$ 13$ billion of imports of insurance services is whether they were produced by resources in these islands. Some doubts might be provoked by the fact that while the United States reported almost $\$ 12$ billion in payments to Bermuda for insurance services in 2004 and over $\$ 10$ billion in 2005, Bermuda reported total exports of insurance services of only \$20 million in that year (Bermuda, Department of Statistics web site). The 
Table 3: Comparison of US Payments and Receipts of Source Countries for Insurancı Services, 2001-2005 (\$US, Millions)

\begin{tabular}{cccccc}
\hline \hline & $\begin{array}{c}\text { US } \\
\text { Payments } \\
\text { To } \\
\text { Bermuda }\end{array}$ & $\begin{array}{c}\text { US } \\
\text { Payments To } \\
\text { Other, Western } \\
\text { Hemisphere }\end{array}$ & $\begin{array}{c}\text { US } \\
\text { Payment To } \\
\text { All } \\
\text { Countries }\end{array}$ & $\begin{array}{c}\text { Bermuda's } \\
\text { Receipts } \\
\text { From All } \\
\text { Countries }\end{array}$ & $\begin{array}{c}\text { Other, } \\
\text { Western } \\
\text { Hemisphere's } \\
\text { Receipts From All } \\
\text { Countries }^{2,3}\end{array}$ \\
\hline 2001 & 7,167 & 1,867 & 16,706 & n.a. & 123 \\
2002 & 7,499 & 1,884 & 22,150 & n.a. & 145 \\
2003 & 10,034 & 2,025 & 25,234 & n.a. & 142 \\
2004 & 11,785 & 4,457 & 29,038 & 20 & 203 \\
2005 & 10,220 & 2,789 & 28,482 & 20 & 195 \\
\hline
\end{tabular}

Note:

1. "Other, Western Hemisphere" refers to Anguilla, Antigua and Barbuda, Aruba, Bahamas, Cuba, Dominica, French Islands (Caribbean), Grenada, Haiti, Jamaica, Netherlands Antilles, St. Kitts and Nevis, St. Lucia, St. Vincent and the Grenadines, Trinidad and Tobago, United Kingdom Islands (Atlantic).

2. Data are not available for Cuba, French Islands (Caribbean), Haiti, and United Kingdom Islands (Atlantic). 3. 2005 data for Trinidad and Tobago are not available. 2004 data are used instead.

Source:

Borga and Mann (2004);

Nephew, Koncz, Borga and Mann (2005);

Koncz, Mann and Nephew (2006);

IMF BOP CD (2007).

Bermuda Department of Statistics website, www.gov.bm , downloaded in July 2007. 
United States reported importing almost \$3 billion in insurance services from “Other Western Hemisphere” in 2005, when these countries reported total worldwide insurance service exports of less than $\$ 200$ million to all destinations. The question raised by these comparisons is whether these service imports reported by the United States were, in fact, produced by labor and physical capital located in the United States, and possibly other developed countries, and financial assets controlled by parent firms in the United States, but attributed to affiliates in the Caribbean? Were the $\$ 17$ billion of reported imports into the United States, in fact, U.S. output that never left the borders of the country? If that were the case, U.S. output was understated and U.S. imports were overstated by this amount in this one service industry.

The shifting of income by paper transactions in order to save on corporate income taxes is not a phenomenon limited to U.S. multinationals. The European Commission has been discussing proposals for a uniform method of allocating income among the countries in which a multinational operates, an idea that has generated strong opposition from several members of the Union. A recent working paper (Fuest, Hemmelgarn, and Ramb, 2006), based on the Deutsche Bundesbank's database on German multinationals' foreign operations and a matched data base on the firms' domestic operations, calculated what firms' distributions of taxable income across countries would be under a hypothetical allocation of income based on sales, employment, and assets, including tangible and intangible assets. The paper showed large discrepancies between the allocated income distribution and the reported one, although the method of allocation did not remove all possibilities of profit shifting to reduce income tax.

\section{The Size of the Distortions}

For the United States, the examples of apparent distortions of measurements of output and trade cited above are confined to a few very small countries, because the smallness of the tax 
havens makes the anomalies between inputs and outputs conspicuous. We very roughly estimate the "true" output and sales from U.S. affiliates in certain tax havens by fitting functions relating measured output or sales to inputs of labor and physical capital across countries that are not, to a major extent, tax havens, or at least contain substantial resources of labor and capital, and applying these functions to the tax havens. The differences between these estimated "true" outputs and sales and the reported ones are our estimates of the distortions in the income and trade accounts of these countries from the reporting by U.S. affiliates.

For 2004, we have estimated the exaggeration of the value added, or output, and of sales of U.S. affiliates in eight tax havens (Ireland, Switzerland, Barbados, Bermuda, United Kingdom Islands in the Caribbean, Western Hemisphere, n.e.c., Hong Kong, and Singapore). The exaggeration of value added, estimated from its relation to labor compensation, was $\$ 33$ billion, about 4 percent of the worldwide total of affiliate sales. The estimated exaggeration in the sales of these affiliates was almost $\$ 360$ billion, over 10 percent of worldwide sales. Since these are relatively small markets, most of the reported sales must have been exports, suggesting a larger impact on exports and imports and balances of payments.

The paper based on German multinationals' data, discussed above, estimated the country distribution of their corporate income in the countries of the European Union under "formula apportionment” and compared it with that under separate accounting, the current system. Germany, a high-tax country, would have gained 6 percent in its corporate tax base from 1996 to 2001. Ireland, among low-tax countries, would have lost 40 percent, Belgium would have lost 27 percent, Luxembourg, 18 percent, and the Netherlands, 65 percent (ibid., p.17). Thus, a shift to formula apportionment, even an apportionment that leaves room for some forms of income 
shifting, as mentioned above, would have had large effects on the location of corporate income in Europe, and corresponding effects on the location of production and trade.

One of the devices used to transfer income without changing the location of labor, physical capital, or intangible assets is to route the ownership of foreign affiliates through other affiliates located in low-tax countries. For majority-owned U.S. affiliates in 1999, 13 percent of assets were in the form of equity investments in other foreign affiliates. By 2005, the share of such assets had increased to 23 percent. In "Other Western Hemisphere," 33 percent of assets were in that form, in Luxembourg, 72 percent, in the Netherlands, 48 percent, and in Switzerland, 35 percent. This is, aside from Switzerland, a different set of countries from the tax havens described above, to which income produced in the United States may have been shifted, and for some of these countries, a claim might be made that the management of investments had been transferred as well. That possibility might be tested by seeing whether there was a corresponding movement of labor or labor income to accompany the transfer of assets.

Some of these problems, in the case of the United States, are dealt with in the BEA's ownership-based accounts (Landefeld, Whichard, and Loewe, 1993) in the sense that they ignore geographical shifts within a single enterprise. However, these are intended as supplements to the standard accounts, not as replacements of them, and the differences from the standard accounts represent conceptual differences, not corrections of distortions. The ownership accounts omit genuine geographical shifts of resources within the same firm, an important element of national accounts, because they focus on ownership, rather than location.

\section{Is There a Solution?}

The existence of these measurement problems is more obvious than the solution. We could move toward a more logical estimate of the location of multinational firms' production by 
discarding the accounting measures supplied by the firms, because they are too badly twisted by tax avoidance maneuvers, and substituting constructed measures. The location of production could be approximated by assuming that it is proportional to inputs of labor and capital, including physical capital, human capital, perhaps represented by labor compensation, and knowledge capital, for which patents and copyrights, or payments for them, could be a proxy. For elements of capital with no definite geographical location, such as many forms of intellectual or other intangible capital, an assignment to the parent firm, or the main location of management activity would be preferable to the current practice of accepting the firm's tax-determined allocation. The same would be true for equity in units of the same multinational firm. One result would be not only a different allocation of production, but a different picture of the flow of trade, since a reallocation of production implies a reallocation of trade.

The problems involved in estimating the location of production and the corresponding flows of exports and imports are not new to the BEA or other statistical authorities. Similar issues arise in estimating sub-national output measures. For example, in estimating gross state product, the BEA must make some geographical allocation of data for central administrative offices of multiestablishment firms. The process is not described very fully, but seems to involve a "reassignment" of nonwage value added in mining, manufacturing, and construction from the states of operating establishments to the states in which the central administrative offices are located (Friedenberg and Beemiller, 1997). Since the nonwage value added is not reported by the central administrative offices, the method assumes that the earnings from the corporation's intangible assets, reported by the individual establishments, should be attributed to the headquarters location of the corporation. As in the international case, the reported earnings 
may be subject to some manipulation for tax reasons of valuations in transactions among the corporation's establishments in different states.

\section{$\underline{\text { Concluding Comments }}$}

The growth in importance of intangible productive assets, combined with tax-induced allocations of intangible assets within multinational firms, are increasingly distorting measures of the location of production, particularly the distribution among countries. Some very crude measures of the size of the distortions are offered here, only for a group of mainly small tax havens, because the effects of tax planning are most visible in small host countries. Even for these countries, the estimated distortion is as large as 10 percent of worldwide sales of U.S.owned affiliates.

While a suggestion is made here for an alternative measure of the location of productive inputs, particularly intangible inputs, the problem runs deeper than that solution. The important role of intangible productive assets, which have no clearly definable location and can be used in many places simultaneously, within the firm, makes any measure of the location of production ambiguous. The ownership of production is more readily definable than the geographical location of production. Perhaps the geographical location of production has little meaning for multinational firms. 


\section{$\underline{\text { References }}$}

Borga, Maria, and Michael Mann (2004), “U.S. International Services: Cross-Border Trade in 2003 and Sales Through Affiliates in 2002,” Survey of Current Business, Vol. 84, No.10, Washington, DC, Bureau of Economic Analysis, October, pp. 25-76.

Denison, Edward F. (1971), “U.S. National Income and Product Estimates: Evaluation and Some Specific Suggestions for Improvement,” Survey of Current Business, Volume 51, Number 7, Part II, Anniversary Issue, The Economic Accounts of the United States:

Retrospect and Prospect, Washington, D.C. U.S. Office of Business Economics, pp. 3644.

Friedenberg, Howard L., and Richard M. Beemiller (1997), “Comprehensive Revision of Gross State Product by Industry, 1977-94,” Survey of Current Business, Vol. 77, No. 6, Washington, DC, Bureau of Economic Analysis, June, pp. 15-41.

Fuest, Clemens, Thomas Hemmelgarn, and Fred Ramb (2006), "How would formula apportionment in the EU affect the distribution and size of the corporate tax base? An analysis based on German multinationals,” Discussion Paper Series 1: Economic Studies No. 20/2006, Frankfurt am Main, Deutsche Bundesbank.

Hines, James R., Jr. (2005), “Do Tax Havens Flourish?” in James M. Poterba, Editor, Tax Policy and the Economy 19, Cambridge, MA, MIT Press, pp. 65-99.

International Monetary Fund (2007), IMF Balance of Payments CD, Washington, DC, July 2007. Koncz, Jennifer, Michael Mann, and Erin Nephew (2006), “U.S. International Services: CrossBorder Trade in 2005 and Sales Through Affiliates in 2004,” Survey of Current Business, Vol. 86, No. 10, Bureau of Economic Analysis, October, pp. 18-74. 
Landefeld, J. Steven, Obie G. Whichard, and Jeffrey H. Loewe (1993), “Alternative Frameworks for U.S. International Transactions,” Survey of Current Business, Vol. 73, No. 12, December, pp. 50-61.

Meade, J.E. (1951), The Theory of International Economic Policy: Vol. 1, The Balance of Payments, London, Oxford University Press.

Mutti, John, and Harry Grubert (2006), "New Developments in the Effect of Taxes on Royalties and the Migration of Intangible Assets Abroad," Paper prepared for the NBER/CRIW Conference on International Service Flows, Bethesda, MD, April 28, 2006.

Nephew, Erin, Jennifer Koncz, Maria Borga, and Michael Mann (2005), “U.S. International Services: Cross-Border Trade in 2004 and Sales Through Affiliates in 2003,” Survey of Current Business, Vol. 85, No. 10, Washington, DC, Bureau of Economic Analysis, October, pp. 25-77.

OECD (Organization for Economic Cooperation and Development), (2006), "Report on the Attribution of Profits to Permanent Establishments, Parts I (General Considerations), II (Banks) and III (Global Trading,” Centre for Tax Policy and Administration, Paris, OECD, December.

U.S. Bureau of Economic Analysis (2004), U.S. Direct Investment Abroad: Final Results from the 1999 Benchmark Survey, Bureau of Economic Analysis, Washington, DC, U.S. Government Printing Office, April.

Young, Allan H. (1975), “New Estimates of Capital Consumption Allowances in the Benchmark Revision of GNP,” Survey of Current Business, Vol. 55, No. 10, , U.S. Bureau of Economic Analysis, October, pp.14-16, 35. 